\title{
Examining transcriptional changes to DNA replication and repair factors over uveal melanoma subtypes
}

\author{
Melanie Kucherlapati ${ }^{1,2}$ [D
}

\begin{abstract}
Background: Uncontrolled replication is a process common to all cancers facilitated by the summation of changes accumulated as tumors progress. The aim of this study was to examine small groups of genes with known biology in replication and repair at the transcriptional and genomic levels, correlating alterations with survival in uveal melanoma tumor progression. Selected components of Pre-Replication, Pre-Initiation, and Replisome Complexes, DNA Damage Response and Mismatch Repair have been observed.

Methods: Two groups have been generated for selected genes above and below the average alteration level and compared for expression and survival across The Cancer Genome Atlas uveal melanoma subtypes. Significant differences in expression between subtypes monosomic or disomic for chromosome 3 have been identified by Fisher's exact test. Kaplan Meier survival distribution based on disease specific survival has been compared by Log-rank test.

Results: Genes with significant alteration include MCM2, MCM4, MCM5, CDC45, MCM10, CIZ1, PCNA, FEN1, LIG1, POLD1, POLE, HUS1, CHECK1, ATRIP, MLH3, and MSH6. Exon 4 skipping in CIZ1 previously identified as a cancer variant, and reportedly used as an early serum biomarker in lung cancer was found. Mismatch Repair protein MLH3 was found to have splicing variations with deletions to both Exon 5 and Exon 7 simultaneously. PCNA, FEN1, and LIG1 had increased relative expression levels not due to mutation or to copy number variation.

Conclusion: The current study proposes changes in relative and differential expression to replication and repair genes that support the concept their products are causally involved in uveal melanoma. Specific avenues for early biomarker identification and therapeutic approach are suggested.
\end{abstract}

Keywords: Replication, Repair, Expression, Uveal melanoma

\section{Background}

Comparatively uncontrolled replication carried out by highly evolutionarily conserved multiprotein complexes, is a process shared by all cancers. Although many other processes including immortality, epithelial to mesenchyme transition, telomere metabolism, metastasis etc. contribute to tumorigenesis, the summation of genomic alterations in a tumor must facilitate replication. Duplication in the transformed cell is achieved at the expense of decreased fidelity, making replication a focal point where heterogeneity

\footnotetext{
Correspondence: mkucherlapati@partners.org
}

${ }^{1}$ Department of Genetics, Harvard Medical School, Boston 02115, MA, USA

2Department of Medicine, Division of Genetics, Brigham and Women's

Hospital, 77 Avenue Louis Pasteur NRB 160B, Boston 02115, MA, USA is created that upon clonal selection leads to tumor expansion and survival. Several individual critical replication genes have been examined in The Cancer Genome Atlas (TCGA) efforts and auxiliary studies, with computational methods placing alterations into known pathways to identify potential targets for precision medicine. However, the behavior of replication factors as a group did not receive analogous systematic investigation, likely because they are thought of as being part of a process rather than a pathway.

TCGA has recently conducted an integrative analysis of uveal melanoma (UVM), and the data providing its molecular foundation are now available to the public as part of the "Rare Tumor Project" [1]. While having a low incidence of 5.1 per million [2] it is the

(c) The Author(s). 2018 Open Access This article is distributed under the terms of the Creative Commons Attribution 4.0 International License (http://creativecommons.org/licenses/by/4.0/), which permits unrestricted use, distribution, and reproduction in any medium, provided you give appropriate credit to the original author(s) and the source, provide a link to the Creative Commons license, and indicate if changes were made. The Creative Commons Public Domain Dedication waiver (http://creativecommons.org/publicdomain/zero/1.0/) applies to the data made available in this article, unless otherwise stated. 
most common intraocular malignancy. UVM is highly lethal, with $50 \%$ of patients developing metastatic disease followed by 6-12 month survival from metastatic diagnosis [3]. Datasets for whole exome sequencing (WES), whole genome sequencing (WGS), mRNA miRNA and lncRNA expression, DNA methylation, identification of immune infiltration, and detailed pathology with clinical outcome were generated. Using these data, the current study examines the status of small groups of genes with known biology in replication and repair at the genomic and transcriptional levels in UVM. Selected components from the Pre-replication, Pre-initiation, Replisome, DNA Damage Repair (DDR), and Mismatch Repair (MMR)

Table 1 A selected list of genes associated with replication and DNA Repair

\begin{tabular}{|c|c|c|}
\hline Gene Symbol & Description & Location \\
\hline ATR & ATR Serine/Threonine Kinase & $3 q 23$ \\
\hline ATRIP & ATR Interacting Protein & $3 p 21.31$ \\
\hline BAP1 & BRCA1 Associated Protein 1 & $3 p 21.1$ \\
\hline CDC45 & Cell Division Cycle 45 & $22 q 11.21$ \\
\hline CHEK1 & Checkpoint Kinase 1 & $11 \mathrm{q} 24.2$ \\
\hline $\mathrm{CIZ1}$ & CDKN1A Interacting Zinc Finger Protein 1 & $9 q 34.11$ \\
\hline EXO1 & Exonuclease 1 & $1 \mathrm{q} 43$ \\
\hline FEN1 & Flap Structure-Specific Endonuclease 1 & $11 q 12.2$ \\
\hline GINS1 & GINS Complex Subunit 1 & $20 p 11.21$ \\
\hline GINS2 & GINS Complex Subunit 2 & $16 q 24.1$ \\
\hline GINS3 & GINS Complex Subunit 3 & $16 q 21$ \\
\hline GINS4 & GINS Complex Subunit 4 & $8 p 11.21$ \\
\hline HUS1 & HUS1 Checkpoint Clamp Component & $7 p 12.3$ \\
\hline LIG1 & DNA Ligase 1 & $19 q 13.33$ \\
\hline MCM2 & Minichromosome Maintenance Complex Component 2 & $3 q 21.3$ \\
\hline MCM3 & Minichromosome Maintenance Complex Component 3 & $6 \mathrm{p} 12.2$ \\
\hline MCM4 & Minichromosome Maintenance Complex Component 4 & $8 q 11.21$ \\
\hline MCM5 & Minichromosome Maintenance Complex Component 5 & $22 q 12.3$ \\
\hline MCM6 & Minichromosome Maintenance Complex Component 6 & $2 q 21.3$ \\
\hline MCM7 & Minichromosome Maintenance Complex Component 7 & $7 q 22.1$ \\
\hline MCM10 & Replication Initiation Factor & 10p13 \\
\hline MLH1 & MutL Homolog 1 & $3 p 22.2$ \\
\hline MLH3 & MutL Homolog 3 & $14 q 24.3$ \\
\hline $\mathrm{MSH} 2$ & MutS Homolog 2 & $2 p 21-p 16.3$ \\
\hline MSH3 & MutS Homolog 3 & $5 q 14.1$ \\
\hline MSH6 & MutS Homolog 6 & $2 \mathrm{p} 16.3$ \\
\hline PCNA & Proliferating Cell Nuclear Antigen & 20p12.3 \\
\hline PMS1 & PMS1 Homolog 1, Mismatch Repair System Component & $2 q 32.2$ \\
\hline PMS2 & PMS1 Homolog 2, Mismatch Repair System Component & $7 \mathrm{p} 22.1$ \\
\hline POLD1 & DNA Polymerase Delta 1, Catalytic Subunit & $19 q 13.33$ \\
\hline POLE & DNA Polymerase Epsilon, Catalytic Subunit & $12 q 24.33$ \\
\hline RAD1 & RAD1 Checkpoint DNA Exonuclease & $5 p 13.2$ \\
\hline RAD17 & RAD17 Checkpoint Clamp Loader Component & $5 q 13.2$ \\
\hline RAD9A & RAD9 Checkpoint Clamp Component A & $11 q 13.2$ \\
\hline RFC4 & Replication Factor C Subunit 4 & $3 q 27.3$ \\
\hline RPA1 & Replication Protein A1 & $17 p 13.3$ \\
\hline RPS19 & Ribosomal Protein S19 & $19 q 13.2$ \\
\hline
\end{tabular}




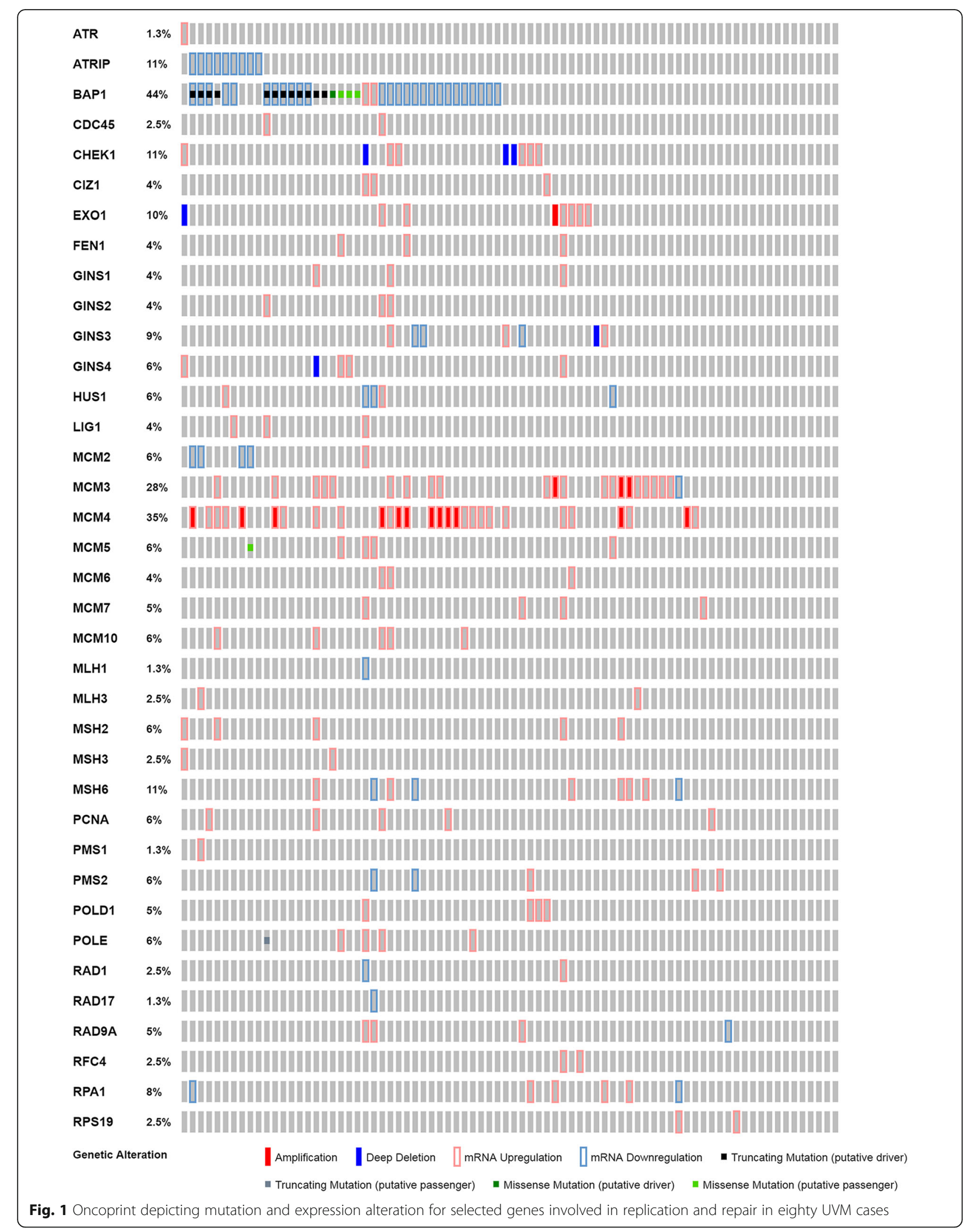


complexes have been investigated for genomic and transcriptional changes across UVM clusters classified by TCGA.

Alterations indicative of replication stress (RS) correlating with aneuploidy, increased malignancy, and decreased survival have been observed, as well as changes to common replication components involved in bypass of replication stress. Generally RS is thought to be an early and strong driving force in tumorigenesis, and is seen over a broad spectrum of cancer types. It is defined as impediment to the replication fork that causes slowing or stalling of the replication machinery and is brought on by "exogenous" and "endogenous" factors [4]. Examples of exogenous causes are radiation, therapeutic treatment, and diet. Endogenous causes include nucleotide pool availability, DNA structures, protein-DNA complexes, reactive oxidation species, transcription and replication complex collision, mutation and expression alteration in tumor suppressor and oncogenes.

This study specifically identifies changes in expression across UVM subtypes to MCM2, MCM4, MCM5, CDC45, MCM10, CIZ1, PCNA, FEN1, LIG1, POLD1, POLE, HUS1, CHECK1, ATRIP, MLH3, and MSH6. Resulting implications for bio-marker and therapeutics are discussed, and a rationale given for the observed alterations.

\section{Methods}

\section{Cluster and mutational analysis}

The cluster analysis relied upon in this study was made by TCGA and is based on Somatic Copy Number Alteration (SCNA) [1]. Clusters are referred to as 1-4 throughout, they correlate with groups A-D by Royer-Bertrand et al. [5]. Mutational findings are based upon data generated by the TCGA Research network and can be found in cBioPortal [6-8].

\section{Differential expression analysis}

In this report expression analysis is made by two algorithms, using the terms "differential" and "relative" to distinguish between them. Differential expression for UVM is defined as mRNA Z Scores (RNA-Seq by Expectation Maximization (RSEM)) (log2) compared to the expression distribution of each gene tumors that are diploid for the gene. The use of the diploid fraction is due to the lack of a normal control for RNA-Seq analysis (matched blood samples for each UVM case were available for DNA analysis). These data are calculated and made available by cBioPortal [8].

\section{Relative expression analysis}

This study defines "relative" expression as mRNA Z Scores (RNA-Seq Reads per Kilobase of Transcript per Million Mapped Reads (RPKM)) ( $\log 2)$ comparison to the UVM tumor cohort average in its entirety, also known as the "average alteration level". These data have been determined specifically for this study and were made for both mRNA and individual exons.

RNA-Seq derived exon expression levels were visualized in heat maps. The Gene Annotation File (GAF) "TCGA.hg19.June2011.gaf" [9] was used to create an exonStartStop.txt file for each gene tested which in turn was used to parse the "UVM.rnaseqv2_illuminahiseq_rnaseqv2_un c_edu_Level_3_exon_quantification_data.data.txt" file [14] to create an "exonRPKM.txt" file used for standard Z score generation. Both files, exonStartStop.txt and exonsRPKM.txt, were run through a verification step to confirm that the appropriate gene, TCGA barcodes, and RNA-Seq data were selected prior to their use. Exon start-stop sites from the exonStartStop.txt file were examined in Integrative Genome Viewer (IGV) $[10,11]$ using RNA-Seq data (9) from the same case to confirm the authenticity of the exon. The "Sashimi Plot" function in IGV was used to identify alternative splicing and isoforms from RNA-Seq data, with "minimum junction coverage" routinely

Table 2 Z Score Comparison Above and Below Zero, Differential versus Relative Expression

\begin{tabular}{|c|c|c|c|}
\hline \multirow[t]{2}{*}{ Gene ID } & \multirow{2}{*}{$\begin{array}{l}\text { Differential Expression (cBioPortal) } \\
\text { Cluster } 1 \text { Above/Below Average }(n=15)\end{array}$} & \multirow{2}{*}{$\begin{array}{l}\text { Relative Expressionn (Study) } \\
\text { Cluster } 1 \text { Above/Below Average }(n=15)\end{array}$} & \multirow[t]{2}{*}{$x^{2}$} \\
\hline & & & \\
\hline BAP1 & $5 / 10$ & $14 / 1$ & 0.0007 \\
\hline \multirow[t]{2}{*}{ RPS19 } & $15 / 0$ & $15 / 0$ & Identical \\
\hline & Cluster $2(n=23)$ & Cluster $2(n=23)$ & \\
\hline BAP1 & $13 / 10$ & $22 / 1$ & 0.0019 \\
\hline \multirow[t]{2}{*}{ RPS19 } & 10/13 & 10/13 & Identical \\
\hline & Cluster $3(n=22)$ & Cluster $3(n=22)$ & \\
\hline BAP1 & $0 / 22$ & $4 / 18$ & 0.0359 \\
\hline \multirow[t]{2}{*}{ RPS19 } & $7 / 15$ & $11 / 11$ & Not Different \\
\hline & Cluster $4(n=20)$ & Cluster $4(n=20)$ & \\
\hline BAP1 & $0 / 20$ & $6 / 14$ & 0.0079 \\
\hline RPS19 & $2 / 18$ & $2 / 18$ & Identical \\
\hline
\end{tabular}


set at "4". Using "R" [12] Z scores were calculated for each exon of each gene by mean-centering with the average alteration level the $\log 2$ transformed RPKM values and dividing by the standard deviation, visualizing high (red), no change/ no expression (white), and low (blue) and arranging data by UVM cluster assignments (1-4) in heat maps.

\section{Placement of cases into "high" and "low" expression groups}

An output file containing $\mathrm{Z}$ scores for each exon was created and used to calculate an average $\mathrm{Z}$ score for each gene. This was regarded reasonable as structural variations to genes were found only with low frequency. UVM cases were sorted into two groups, those with average Z scores "above" and those "below" zero. After group designation, the cluster [1-4] each case belonged to was identified and the numbers of cases "high" and "low" for each cluster counted. Significant differences between " 1 and 2 " versus " 3 and 4" were determined by Fisher's exact (two tailed), using GraphPad Quick Calcs. Because very few genes and few cases (total $n=80$, in each cluster $n=15$ through 23) were examined, "q" values were not calculated, with the rationale that doing so might increase "type II" errors. Since placement of

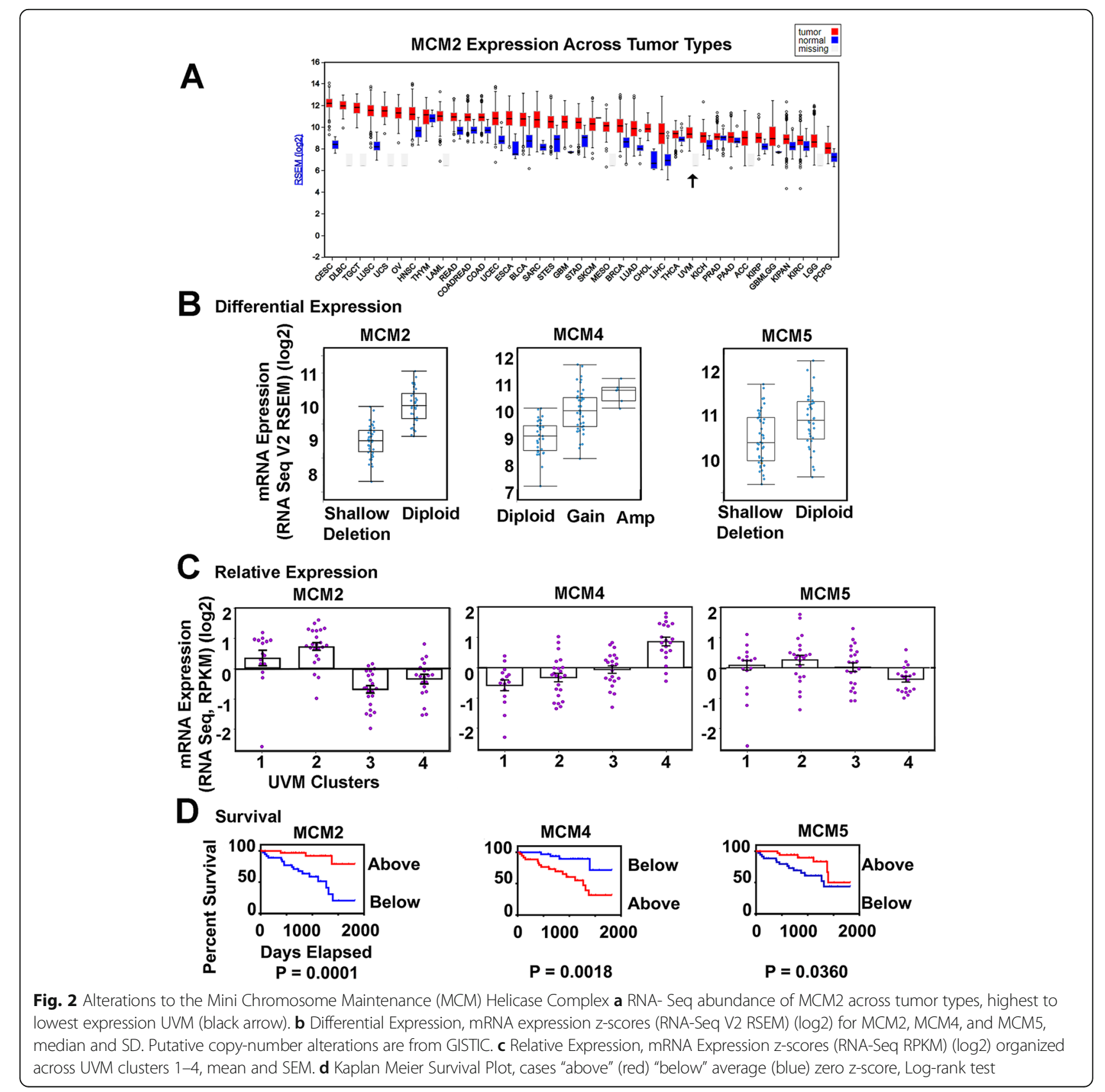


cases into "high" and "low" grouping was made relative to the total tumor cohort average, conjecturally, all cases "below" the tumor cohort average could also be "above" an average made from appropriate adjacent normal tissues, which was not available for RNA analysis in UVM samples. The procedure was evaluated using BAP1 and RPS19 as test genes.

\section{Clinical data and survival analysis}

The TCGA UVM cohort was made up of eighty matched tumor and normal blood specimens. Tumors were obtained from patients that did not have previous systemic chemotherapy or focal radiation, with appropriate consent obtained from institutional review boards. A panel of five histopathologists with expertise in ocular pathology and melanoma, examined hematoxylin and eosin stained sections from paraffin embedded tumors defining tumor extent, cell morphology, pigmentation, mitotic index, and the presence of tumor-infiltrating lymphocytes and macrophages. The following information was also curated: "tumor status" (date of last contact), "vital status" (dead/alive), "date of last contact", "date of death", "cause of death", "other cause of death", "new tumor event after initial treatment", "histology of new tumor event", "site of new tumor", "other site/new event", "date of new event", "additional surgery", "additional treatment/radiation", "additional treatment/pharmaceutical".
In principal four types of survival analysis can be made with TCGA clinical data. "overall survival" defined as the period from date of diagnosis until death from any cause, "progression-free interval" from date of diagnosis until the occurrence of an event in which the patient with or without the tumor does not get worse, "disease-free interval" date of diagnosis until first recurrence, and "disease specific survival" diagnosis date until death from the specific cancer type. All UVM survival curves constructed for this study were "disease specific survival" curves, as recommended by TCGA Pan Cancer Guidelines [13]. Kaplan Meier survival plots were constructed using GraphPad Prism 6.0 software. The Log-rank (Mantel-Cox) and Hazard Ratio tests were used to determine significance.

\section{Results}

\section{BAP1 and RPS19}

A total of thirty-seven genes (Table 1) were observed for mutations and differential expression (Fig. 1). BAP1 and RPS19 differential and relative expression were compared (Table 2). Examination of BAP1 differential expression $\mathrm{Z}$ scores calculated by cBioPortal, showed a two-fold greater inclusion of cases "below" average expression. For this tumor type due to the relationship of monosomy 3 to subtypes and survival, the approach using an estimated reference (the diploid fraction) alters comparison to relative expression

Table 3 Relative Expression and Survival Correlation of Pre-Replication and Pre-Initiation Complex Factors

\begin{tabular}{|c|c|c|c|c|c|c|c|c|c|}
\hline \multirow[t]{2}{*}{ Gene } & $\begin{array}{l}\text { UVM Cluster } 1 \\
\text { Above/Below } \\
\text { Average (\%/\%) }\end{array}$ & \multirow{2}{*}{$\begin{array}{l}\text { UVM Cluster } 2 \\
\text { Above/Below } \\
\text { Average (\%/\%) } \\
n=23\end{array}$} & \multirow{2}{*}{$\begin{array}{l}\text { UVM Cluster } 3 \\
\text { Above/Below } \\
\text { Average (\%/\%) } \\
n=22\end{array}$} & \multirow{2}{*}{$\begin{array}{l}\text { UVM Cluster } 4 \\
\text { Above/Below } \\
\text { Average (\%/\%) } \\
n=20\end{array}$} & \multirow{2}{*}{$\begin{array}{l}P \text { Value } 1 \& 2 \\
\text { vs } 3 \& 4 \text { Fisher's } \\
\text { Exact Two } \\
\text { Tailed }\end{array}$} & \multirow[t]{2}{*}{$\begin{array}{l}\text { Total } \\
\text { Cases } \\
\text { Above } \\
\text { Average }\end{array}$} & \multirow[t]{2}{*}{$\begin{array}{l}\text { Total } \\
\text { Cases } \\
\text { Below } \\
\text { Average }\end{array}$} & \multirow[t]{2}{*}{$\begin{array}{l}\text { Kaplan } \\
\text { Meier } \\
\text { Worse } \\
\text { Survival }\end{array}$} & \multirow[t]{2}{*}{$\begin{array}{l}\text { Kaplan } \\
\text { Meier } \\
\text { Log-rank }\end{array}$} \\
\hline & $n=15$ & & & & & & & & \\
\hline \multicolumn{10}{|c|}{ Pre-Replication Complex } \\
\hline MCM2 & $12 / 3(80 / 20)$ & 20/3 (87/13) & $3 / 19(14 / 86)$ & $5 / 15(25 / 75)$ & $<0.0001$ & 40 & 40 & Below & 0.0001 \\
\hline MCM3 & $7 / 8(47 / 53)$ & $10 / 13(43 / 57)$ & $7 / 15(32 / 68)$ & $12 / 8(60 / 40)$ & 1.0000 & 36 & 44 & NA & 0.5514 \\
\hline MCM4 & $2 / 13(13 / 87)$ & $6 / 17(26 / 74)$ & $11 / 11(50 / 50)$ & 18/2 (90/10) & $<0.0001$ & 37 & 43 & Above & 0.0018 \\
\hline MCM5 & $9 / 6(60 / 40)$ & 16/7 (70/30) & $11 / 11(50 / 50)$ & $4 / 16(20 / 80)$ & 0.0133 & 40 & 40 & Below & 0.0360 \\
\hline MCM6 & $6 / 9(40 / 60)$ & 9/14 (39/61) & $15 / 7(68 / 32)$ & $19 / 1(95 / 5)$ & 0.0002 & 49 & 31 & NA & 0.1809 \\
\hline MCM7 & $3 / 12(20 / 80)$ & $17 / 6(74 / 26)$ & $11 / 11(50 / 50)$ & $11 / 9(55 / 45)$ & 1.0000 & 42 & 38 & NA & 0.2614 \\
\hline \multicolumn{10}{|c|}{ Pre-Initiation Complex } \\
\hline CDC45 & $5 / 10(33 / 67)$ & $6 / 17(26 / 74)$ & $14 / 8(64 / 36)$ & $15 / 5(75 / 25)$ & 0.0007 & 40 & 40 & NA & 0.4409 \\
\hline GINS1 & $5 / 10(33 / 67)$ & $8 / 15(35 / 65)$ & $6 / 16(27 / 73)$ & $15 / 5(75 / 25)$ & 0.1074 & 34 & 46 & NA & 0.1774 \\
\hline GINS2 & $8 / 7(53 / 47)$ & $11 / 12(48 / 52)$ & 14/8 64/36) & $9 / 11(45 / 55)$ & 0.8229 & 42 & 38 & NA & 0.1965 \\
\hline GINS3 & $11 / 4(73 / 27)$ & $11 / 12(48 / 52)$ & 8/14 (36/64) & $11 / 9(55 / 45)$ & 0.2735 & 41 & 39 & NA & 0.6131 \\
\hline GINS4 & $6 / 9(40 / 60)$ & $12 / 11(52 / 48)$ & $11 / 11(50 / 50)$ & $9 / 11(45 / 55)$ & 1.0000 & 38 & 42 & NA & 0.5714 \\
\hline MCM10 & $3 / 12(20 / 80)$ & 9/14 (39/61) & 9/13 (41/59) & $15 / 5(75 / 25)$ & 0.0261 & 36 & 44 & NA & 0.2409 \\
\hline $\mathrm{ClZ1}$ & $12 / 3(80 / 20)$ & 15/8 (65/35) & $13 / 9(59 / 41)$ & $2 / 18(10 / 90)$ & 0.0019 & 42 & 38 & Below & 0.0032 \\
\hline
\end{tabular}


for genes located on chromosome 3. SCNA subtypes 3 and 4 are both monosomic for chromosome 3 and constitute approximately half the total tumor cohort. In contrast using RPS19, a gene which codes for a 40S Ribosome complex protein with cytological location at chromosome 19q13.2, showed no significant difference in relative expression found between the study method and cBioPortal values. UVM do not have significant SCNA for chromosome 19. The four additional cases found in "below" of cluster 3 are due to the use of RSEM verses RPKM. These results show incongruity between differential expression about an estimated normal value and relative expression about a tumor cohort average, when high numbers of cases are not diploid. It should be noted explicitly that presentation of the discrepancy is not meant to claim one set of calculations superior to the other, but to explain why additional calculations were made for relative expression.

\section{Pre-replication and pre-initiation complexes}

Differential expression of all Mini-Chromosome Maintenance (MCM) helicase components of the pre-replication complex is increased over a wide range of tumor types. The results for MCM2 (3q21.3) specifically are given in Fig. 2 [14]. Relative expression profiles document MCM2 drops below the tumor average significantly in UVM clusters 3 and 4 ( $P=0.0001)$ (Table 3$)$, correlating with increased malignancy and decreased disease specific survival $(P=$ 0.0001). Half of the helicase complex components (MCM2-7) are located on chromosomes found by TCGA to have copy number alterations that include monosomy

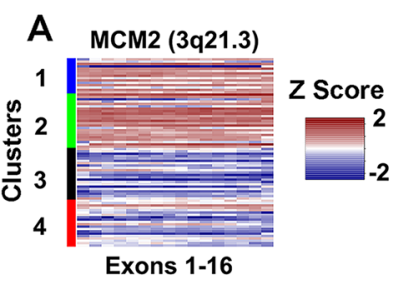

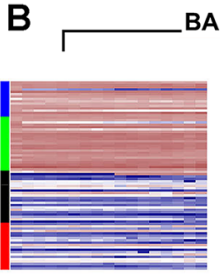

Exons 1-17

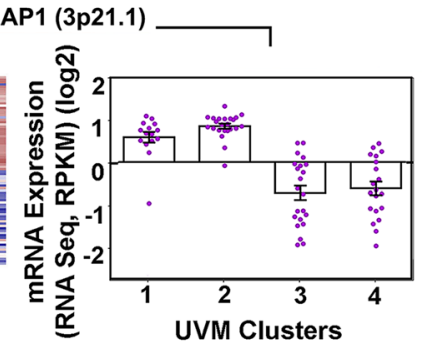

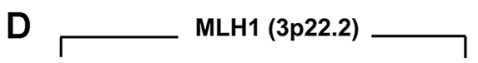

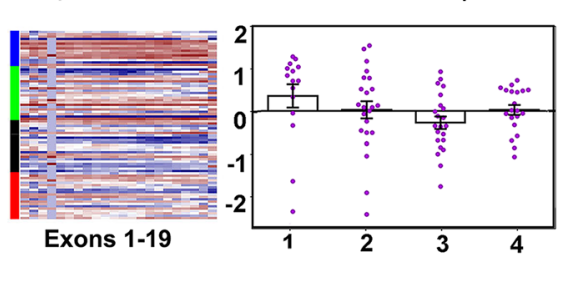

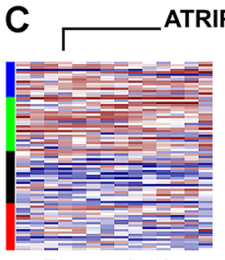

Exons 1-14 ATRIP (3p21.31)

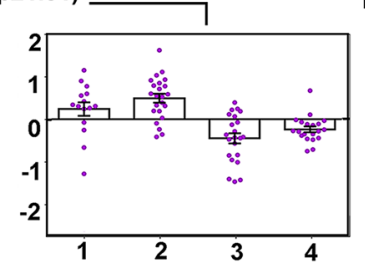

E

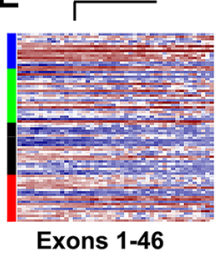

ATR (3q23)

$\mathbf{F}$

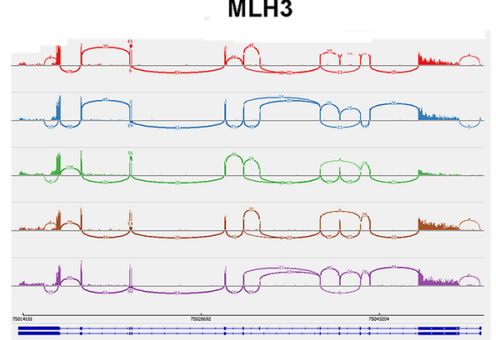

G

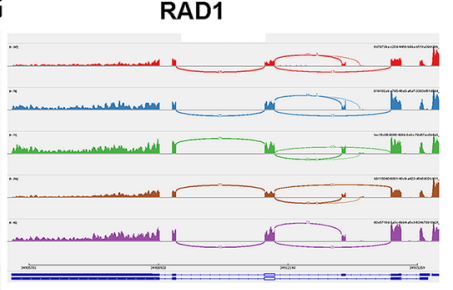

Fig. 3 mRNA Expression from Chromosome 3 Genes. a Heatmap of MCM2 mRNA relative expression for exons 1-16, organized by UVM subtype; high expression (red), no change (white), low (blue). b Heatmap of BAP1 exons 1-17 with corresponding relative expression scatter plot (mean, SEM). c ATRIP (d) MLH1 (e) ATR. f Sashimi plot (from Integrative Genome Viewer) depicting alternative splicing of MLH3. g Sashimi plot, RAD1 
chromosome 3, 8q and $6 \mathrm{p}$ gains. A comparison of other genes in this study found on chromosome 3 indicates expression levels do not always simply correlate with SCNA (Fig. 3), reflecting the TCGA finding that expression subtypes are only partially concordant with SCNA subtypes [1].

Conversely, MCM4 (8q11.21) expression is increased in clusters 3 and 4, with escalation correlating to worse survival that correlate with SCNA gains to chromosome $8 \mathrm{q}$ in cluster 4 $(P=0.0018)$ (Fig. 2, Table 3). MCM5 (22q12.3) has lower relative expression in UVM clusters 3 and 4 , with cases having worse survival. For MCM5, the $P$ values are significant but less convincing $(P=0.036)$.
Other genes associated with the pre-replication complex and examined in this study include CDC45, GINS1-4, MCM10, and CIZ1. CDC45 and MCM10 were both highly expressed in the higher risk subtypes, but did not correlate with survival changes (Table 3). GINS1-4 relative expression was not altered across the clusters. CIZ1 [15-20], had highly significant difference between the clusters, with lower relative expression correlating to higher risk subtypes and decreased survival $(P=0.0019)$ (Fig. $4 \mathrm{~b}$-c, Table 3$)$. Evidence of exon 4 skipping previously seen in Ewing tumor [21] and Lung Cancer [22] and in the $\mathrm{C}$ terminal region was found

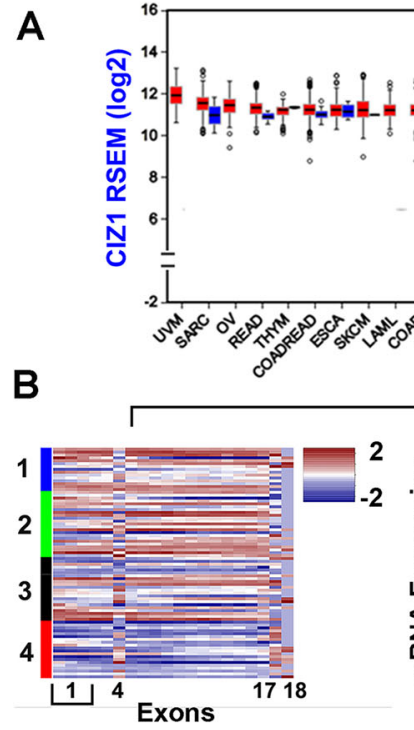

CIZ1 Expression Across Tumor Types
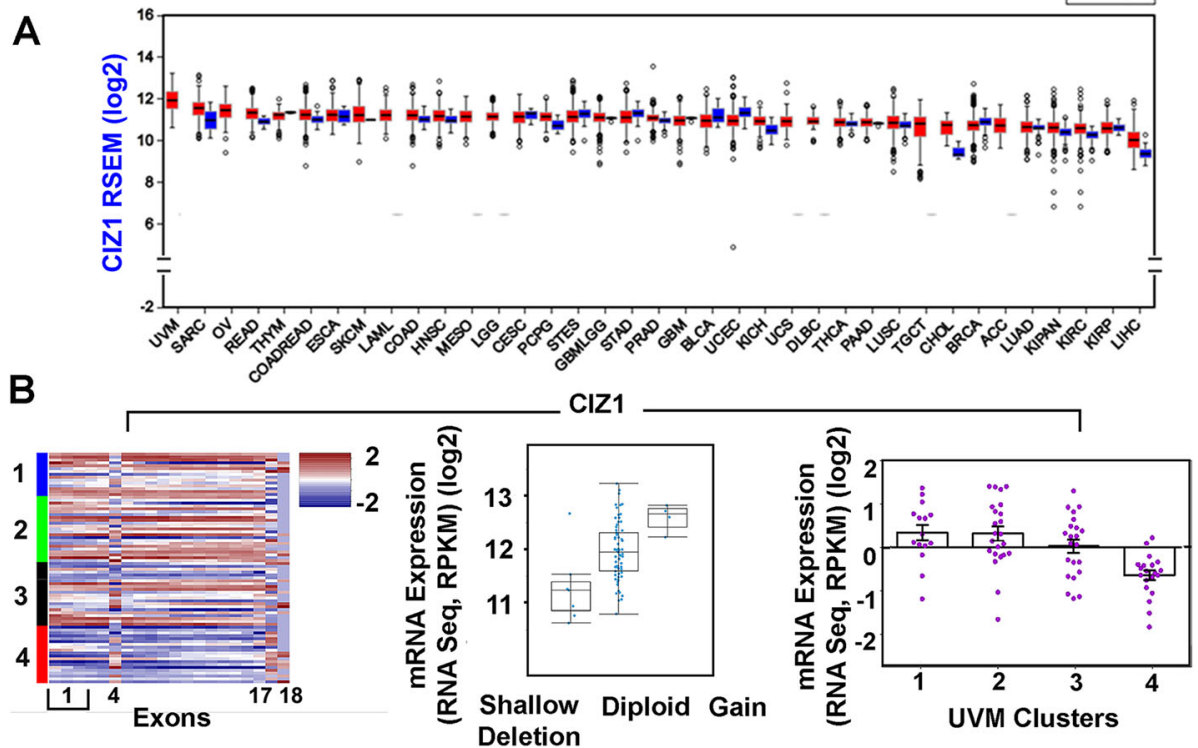

C
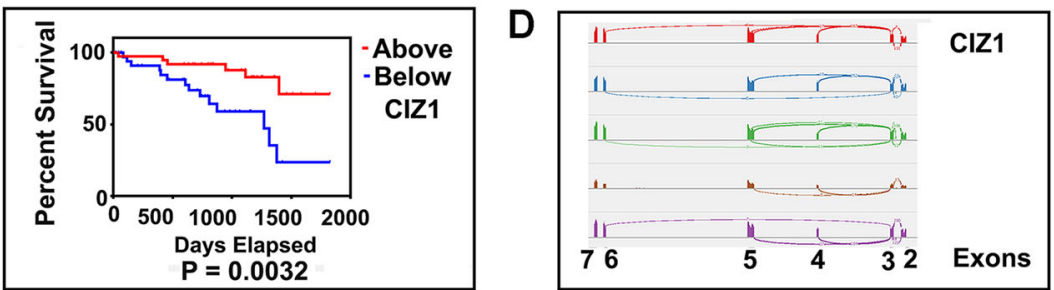

E

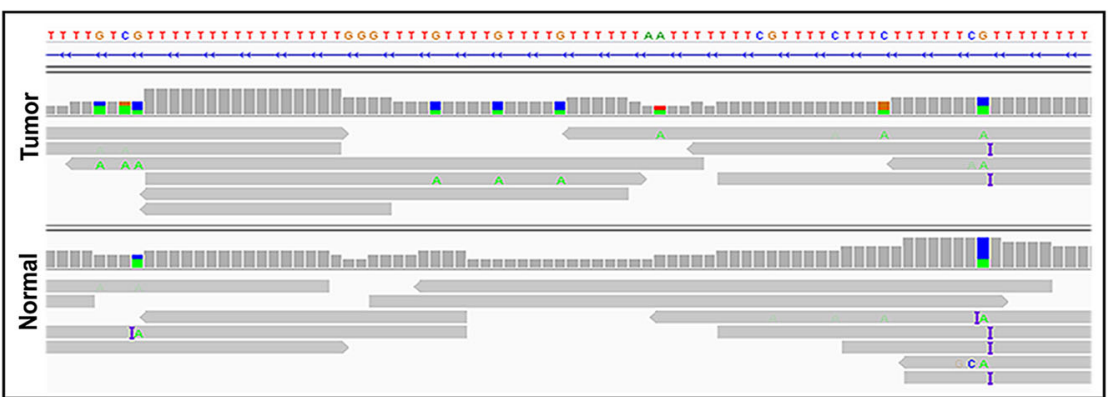

Fig. $4 \mathrm{CIZ1}$ (a) Differential Expression, across tumor types. $\mathbf{b}$ Heatmap of CIZ1 relative expression with exon1 alternative splicing and variation to exons 4, 17, and 18. CIZ1 Differential Expression and CIZ1 relative expression. c Kaplan Meier survival plot (Log-rank test). d Sashimi plot, exon 4 skipping. e CIZ1 Intron 3 mononucleotide repeat (hg19:130,950,210-130,950,372), adenine insertions (purple bar) 
in the CIZ1 heatmap (Fig. 4b) and in RNA-Seq using the Sashimi Plot function in IGV (Fig. 4d). CIZ1 intron 3 contains a mononucleotide repeat previously associated with exon 4 skipping mechanistically, and hypothesized to be the result of MMR deficiency [21]. Fifty out of 80 UVM tumors had low pass WGS for tumor and normal counterpart tissues as well as tumor RNA-Seq. These cases were examined in IGV for alterations to Intron 3 (hg19:130,950,210-130,950,372). Almost all tumors and normal samples had some alteration (Fig. 4e). Clear identification of Microsatellite Instability (MSI) from sequencing artefact wasn't possible. These results are discussed more fully below.

\section{Replisome, DNA damage response, mismatch repair proteins}

PCNA, FEN1, LIG1, and HUS1 were found to have increased relative expression across clusters 1-4 (Fig. 5). PCNA and HUS1 increase correlated significantly with worse survival, FEN1 and LIG1 did not (Table 4). RFC4 and RPA1did not have differences (data not given).

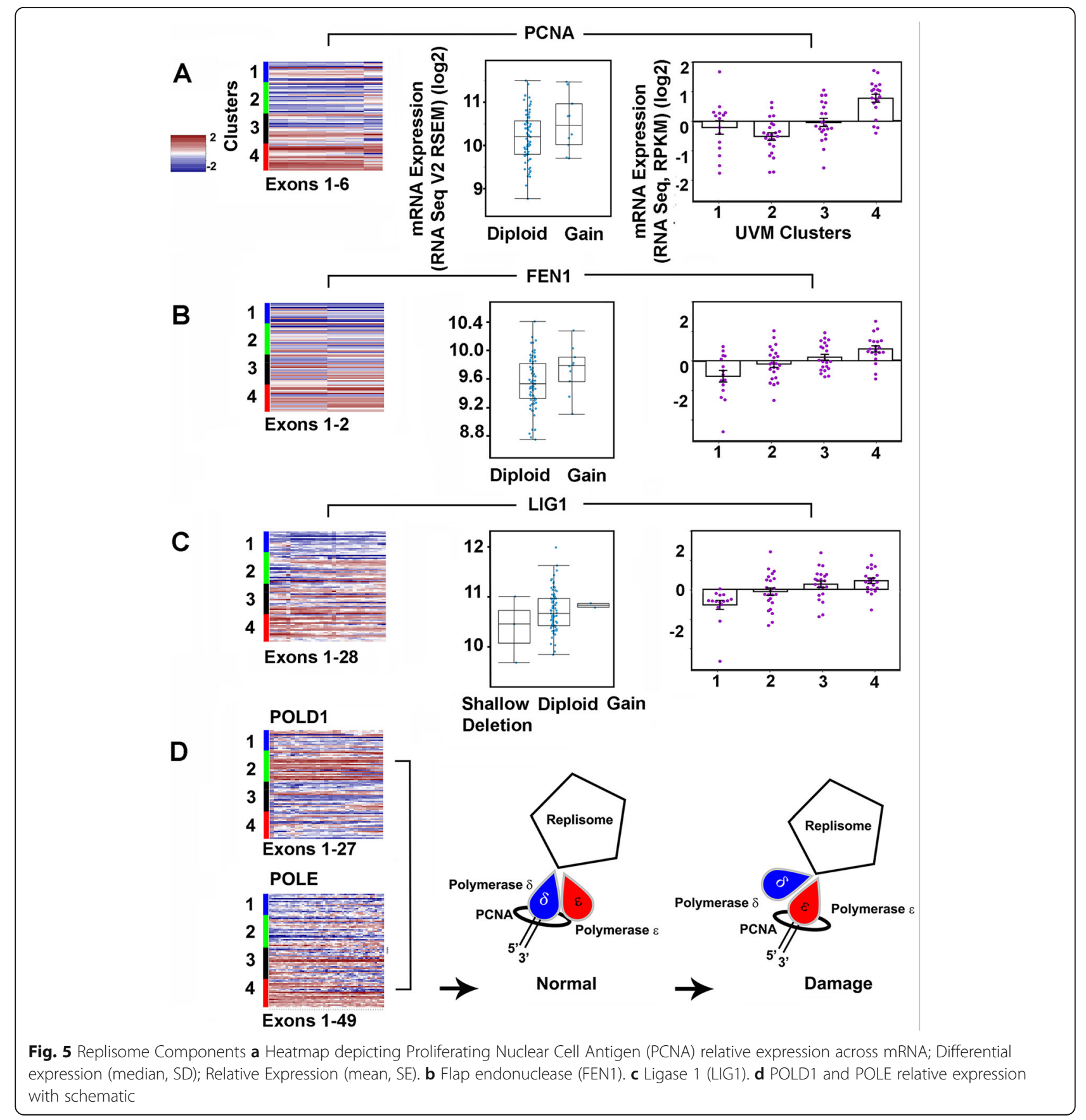


POLD1 relative expression was significantly different in clusters 1 and 2 compared to 3 and 4, survival correlation was not $(P=0.06$, Log rank). POLE expression was not significantly different across clusters 1 through 4 . Examining POLD1 and POLE clusters $3 \& 4$ to each other however, showed significant difference in the number of cases "above" and "below" the mean $(P=0.0042)$, indicating clusters 3 and 4 had more cases with higher than average POLE expression than POLD1 (Fig. 5).

RAD1, RAD9A, and RAD17, members of the DDR complex did not have significant expression or survival differences. RAD1 showed evidence of alternative splicing involving exon 3 previously reported as a natural isoform (Fig. 3). ATRIP was significantly decreased in the more malignant clusters 3 and 4 and this decrease correlated with survival decrease (Table 4), HUS1 was increased.

Mismatch repair proteins MLH3 and MSH6 had significant expression differences across clusters but no survival advantages or disadvantages (Table 5). MLH1 relative expression did not completely behave as anticipated from simple correlation with chromosome 3 loss (Fig. 3). RNA-Seq data was examined for several MMR genes in IGV and further evidence of exon skipping and alternative splicing was found for MLH3. An isoform was identified by Sashimi plots that had deletions in both exons 7 and exon 5 simultaneously (Fig. 3f).

\section{Discussion}

Clinical treatments for UVM fall under the broad categories of radiation, surgery, laser, and novel therapies for primary disease [3]. Despite measures, metastatic tumor cells persist in up to half of patients leading to death. It is probable that until therapy can halt the procession of the replication complex in a non-harmful tumor specific manner, that there will always be the potential for the selection of persistent cells. The rationale for focusing on replication and repair genes is to identify changes that directly account for the persistent tumor cells that implicitly make appropriate targets. The replisome is inherently highly processional and is kept under control by complexes of proteins that determine where, when, and how it functions in normal development, homeostasis, and in the tumor phenotype. This study suggests the replisome is increasingly unfettered by the inactivation of controlling complexes such as the origin of replication proteins, DDR, and MMR complexes as UVM progresses in malignancy. Schematic diagrams are presented (Figs. 6, 7 and 8) identifying selected genes of those complexes examined, and how they are thought to function normally.

Expression alteration to genes that create RS was found in untreated UVM, clearly indicating therapeutic radiation was not responsible for its initiation. On the basis of high frequency, the earliest mutations in UVM are thought to be to the guanine nucleotide binding proteins (GTPases) GNAQ and GNA11. It is a plausible hypothesis that alteration to these genes would directly or indirectly result in alterations to nucleotide pool availability in the nucleus, providing an early and endogenous cause of RS. Thought to be an early and driving event in cancer generally, there has been suggestion RS might be therapeutically targetable $[23,24]$.

Table 4 Relative Expression and Survival Correlation of Replisome and DNA Damage Response Factors

\begin{tabular}{|c|c|c|c|c|c|c|c|c|c|}
\hline \multirow[t]{2}{*}{ Gene } & \multirow{2}{*}{$\begin{array}{l}\text { UVM Cluster } 1 \\
\text { Above/Below } \\
\text { Average (\%/\%) } \\
n=15\end{array}$} & \multirow{2}{*}{$\begin{array}{l}\text { UVM Cluster } 2 \\
\text { Above/Below } \\
\text { Average (\%/\%) } \\
n=23\end{array}$} & \multirow{2}{*}{$\begin{array}{l}\text { UVM Cluster } 3 \\
\text { Above/Below } \\
\text { Average (\%/\%) } \\
n=22\end{array}$} & \multirow{2}{*}{$\begin{array}{l}\text { UVM Cluster } 4 \\
\text { Above/Below } \\
\text { Average (\%/\%) } \\
n=20\end{array}$} & \multirow{2}{*}{$\begin{array}{l}P \text { Value } 1 \& 2 \\
\text { vs } 3 \& 4 \text { Fisher's } \\
\text { Exact Two } \\
\text { Tailed }\end{array}$} & \multirow{2}{*}{$\begin{array}{l}\text { Total } \\
\text { Cases } \\
\text { Above } \\
\text { Average }\end{array}$} & \multirow{2}{*}{$\begin{array}{l}\text { Total } \\
\text { Cases } \\
\text { Below } \\
\text { Average }\end{array}$} & \multirow{2}{*}{$\begin{array}{l}\text { Kaplan } \\
\text { Meier } \\
\text { Worse } \\
\text { Survival }\end{array}$} & \multirow[t]{2}{*}{$\begin{array}{l}\text { Kaplan } \\
\text { Meier } \\
\text { Log-rank }\end{array}$} \\
\hline & & & & & & & & & \\
\hline \multicolumn{10}{|c|}{ Replisome } \\
\hline PCNA & $8 / 7(40 / 60)$ & $4 / 19(17 / 83)$ & $8 / 14(36 / 64)$ & $17 / 3(85 / 15)$ & 0.0147 & 37 & 43 & Above & 0.0280 \\
\hline FEN1 & $5 / 10(33 / 67)$ & $9 / 14(39 / 61)$ & $11 / 11(50 / 50)$ & $17 / 3(85 / 15)$ & 0.0132 & 42 & 38 & Above & 0.0884 \\
\hline LIG1 & $1 / 14(7 / 93)$ & 10/13 (44/56) & $16 / 6(73 / 27)$ & $15 / 5(75 / 25)$ & 0.0001 & 42 & 38 & NA & 0.2590 \\
\hline POLD1 & $7 / 8(47 / 53)$ & $17 / 6(74 / 26)$ & $7 / 15(32 / 68)$ & $6 / 14(30 / 70)$ & 0.0067 & 37 & 43 & Below & 0.0597 \\
\hline POLE & $4 / 11(27 / 73)$ & $14 / 9(61 / 39)$ & $11 / 11(50 / 50)$ & $16 / 4(80 / 20)$ & 0.1761 & 45 & 35 & Above & 0.0990 \\
\hline \multicolumn{10}{|c|}{ DNA Damage Response } \\
\hline HUS1 & $7 / 8(47 / 53)$ & 9/14 (39/61) & $12 / 10(55 / 45)$ & 18/2 (90/10) & 0.0124 & 46 & 34 & Above & 0.0278 \\
\hline RAD9A & $9 / 6(60 / 40)$ & $10 / 13(43 / 57)$ & $13 / 9(59 / 41)$ & $16 / 4(80 / 20)$ & 0.1105 & 48 & 32 & NA & 0.8086 \\
\hline RAD1 & $8 / 7(53 / 47)$ & $10 / 13(43 / 57)$ & 10/12 (45/55) & $16 / 4(80 / 20)$ & 0.2609 & 44 & 36 & NA & 0.1076 \\
\hline RAD17 & $8 / 7(53 / 47)$ & 9/14 (39/61) & $9 / 13(41 / 59)$ & $16 / 4(80 / 20)$ & 0.2624 & 42 & 38 & NA & 0.5653 \\
\hline ATR & $11 / 4(73 / 27)$ & $10 / 13(44 / 56)$ & $6 / 16(27 / 73)$ & $13 / 7(65 / 35)$ & 0.5021 & 40 & 40 & NA & 0.8707 \\
\hline CHEK1 & $4 / 11(27 / 73)$ & $8 / 15(35 / 65)$ & $12 / 10(55 / 45)$ & $15 / 5(75 / 25)$ & 0.0041 & 39 & 41 & NA & 0.3072 \\
\hline ATRIP & $11 / 4(73 / 27)$ & $19 / 4(83 / 17)$ & $6 / 16(27 / 73)$ & $2 / 18(10 / 90)$ & 0.0001 & 38 & 42 & Below & 0.0001 \\
\hline
\end{tabular}


Table 5 Relative Expression and Survival Correlation of Mismatch Repair Genes

\begin{tabular}{|c|c|c|c|c|c|c|c|c|c|}
\hline \multirow[t]{2}{*}{ Gene } & \multirow{2}{*}{$\begin{array}{l}\text { UVM Cluster } 1 \\
\text { Above/Below } \\
\text { Average (\%/\%) } \\
n=15\end{array}$} & \multirow{2}{*}{$\begin{array}{l}\text { UVM Cluster } 2 \\
\text { Above/Below } \\
\text { Average (\%/\%) } \\
n=23\end{array}$} & \multirow{2}{*}{$\begin{array}{l}\text { UVM Cluster } 3 \\
\text { Above/Below } \\
\text { Average (\%/\%) } \\
n=22\end{array}$} & \multirow{2}{*}{$\begin{array}{l}\text { UVM Cluster } 4 \\
\text { Above/Below } \\
\text { Average (\%/\%) } \\
n=20\end{array}$} & \multirow{2}{*}{$\begin{array}{l}P \text { Value } 1 \& 2 \\
\text { vs } 3 \& 4 \text { Fisher's } \\
\text { Exact Two } \\
\text { Tailed }\end{array}$} & \multirow{2}{*}{$\begin{array}{l}\text { Total } \\
\text { Cases } \\
\text { Above } \\
\text { Average }\end{array}$} & \multirow[t]{2}{*}{$\begin{array}{l}\text { Total } \\
\text { Cases } \\
\text { Below } \\
\text { Average }\end{array}$} & \multirow{2}{*}{$\begin{array}{l}\text { Kaplan } \\
\text { Meier } \\
\text { Worse } \\
\text { Survival }\end{array}$} & \multirow[t]{2}{*}{$\begin{array}{l}\text { Kaplan } \\
\text { Meier } \\
\text { Log-rank }\end{array}$} \\
\hline & & & & & & & & & \\
\hline MLH1 & $11 / 4(73 / 27)$ & $13 / 10(57 / 43)$ & $7 / 15(32 / 68)$ & $11 / 9(55 / 45)$ & 0.0781 & 42 & 38 & NA & 0.9990 \\
\hline MLH3 & $6 / 9(40 / 60)$ & 9/14 (39/61) & $12 / 10(55 / 45)$ & $16 / 4(80 / 20)$ & 0.0242 & 43 & 37 & NA & 0.3170 \\
\hline $\mathrm{MSH} 2$ & $7 / 8(47 / 53)$ & $12 / 11(52 / 48)$ & $9 / 13(41 / 59)$ & $16 / 4(80 / 20)$ & 0.5004 & 44 & 36 & NA & 0.7404 \\
\hline MSH3 & $8 / 7(53 / 47)$ & $11 / 12(48 / 52)$ & 9/13 (41/59) & $16 / 4(80 / 20)$ & 0.5004 & 44 & 36 & NA & 0.3593 \\
\hline MSH6 & 4/11 (27/73) & $13 / 10(57 / 43)$ & $10 / 12(46 / 54)$ & $16 / 4(80 / 20)$ & 0.0357 & 43 & 37 & NA & 0.7278 \\
\hline PMS1 & $6 / 9(40 / 60)$ & $9 / 14(39 / 61)$ & $9 / 13(41 / 59)$ & $16 / 4(80 / 20)$ & 0.1165 & 40 & 40 & NA & 0.3997 \\
\hline PMS2 & $8 / 7(53 / 47)$ & $15 / 8(65 / 35)$ & $11 / 11(50 / 50)$ & $14 / 6(70 / 30)$ & 1.0000 & 48 & 32 & NA & 0.7110 \\
\hline EXO1 & $8 / 7(53 / 47)$ & $10 / 13(43 / 57)$ & $4 / 18(18 / 82)$ & $13 / 7(65 / 35)$ & 0.6526 & 35 & 45 & NA & 0.4349 \\
\hline
\end{tabular}

This study specifically found changes to the MCM helicase complex. MCM2-7 components effectually act to "license" the firing of origins of replication during G1-phase of the cell cycle, determining the multiple nascent origins that replicate during $\mathrm{S}$ phase. A recent comprehensive review has been made by Riera et al. [25]. The complex is thought to load in excess, with dormant origins becoming active when nearby replication forks have stalled functionally serving as backup. Mouse models deficient in MCM components have high rates of cancer and genome instability [26-30], which supports the concept of relative deficiency of MCM factors in the more malignant UVM subtypes. Decrease in MCM2 is thought to reduce replication initiation in gene rich early replicating regions, and to increase genetic damage at a subset of gene rich locations [31] without changing the replication rate. Another putative function for MCM2 due to its histone binding and chaperone capacity may be to orchestrate histone dynamics during replication [32], and it has also been linked conceptually to transcription [33]. UVM appear to have MCM concentration alterations including decreased MCM2, increased MCM4 and decreased MCM5 that correlate with increased malignancy and decreased survival. Overexpression of MCM4 has been found previously in multiple transformed cell lines and numerous tumor types $[34,35]$. Multiple kinase signaling pathways are known to target MCM4. It is thought to mediate the repression of late origin firing and provide an intrinsic regulatory domain for signal integration coordinating origin activation and replication fork progression under RS [36]. The unbalanced expression of MCM2-7 individual components likely affects the quantitative amount of functional helicase available, lowering the ability to load in excess and contributing to unregulated replication.

Once the pre-replication complex is augmented with proteins CDC45 and GINS1-4 it is designated as a "pre-initiation complex", CIZ1 (also known as Cip1-interacting zinc finger protein 1) is thought to function in this context [20]. This interesting gene plays a role in cell cycle control and replication by interaction with Cip1/Waf1 [15], and coordinating cyclin $\mathrm{E}$ and A functions in the nucleus [17]. It is required for cells to enter into S phase [20]. CIZ1 physically tethers to non-chromatin nuclear structures in the nuclear matrix, and co-localizes in immune-histochemical studies with PCNA [15]. Two functionally distinct domains exist, an N-terminal domain involved in replication and a C-terminal domain comprising the nuclear matrix anchor [16]. Targeted depletion of transcripts decreases proliferation in vitro [15]. Differential expression plots show the gene is most highly expressed in UVM (Fig. 4). Relative expression across the TCGA SCNA subtypes shows clusters 1,2 , and 3 have CIZ1 expression above the alteration level and cases below are primarily in subtype 4 . CIZ1 must be available in enough quantity in subtype 4 to provide the replication function. Relative paucity and alternative splicing likely creates less than optimum conditions for nuclear anchor functioning. Almost all UVM cases examined show evidence of exon 4 alteration previously reported in other cancers as well as alteration to the carboxyl end of the protein. Variant mRNA created by alternative splicing are found in cancers and other disorders that appear to alter protein localization [19]. Variant CIZ1 has recently been published as a circulating biomarker for early-stage lung cancer [22] suggesting the same might be possible for UVM patients.

The findings for CIZ1 led to identification a mononucleotide repeat in Intron 3 with possible MSI. Almost no evidence points to the involvement of MMR components as drivers for UVM, and examination of mutation rate does not show logarithmic elevation typical of MMR deficient tumors. Exon skipping was observed in MLH3 (MLH3 $\Delta$ exon5/ $\Delta$ exon7), a protein that interacts with MLH1 directly. MLH3 $\Delta$ exon7 has been previously described [37] and in that study the isoform lacked MLH1 binding activity suggesting a mechanism 


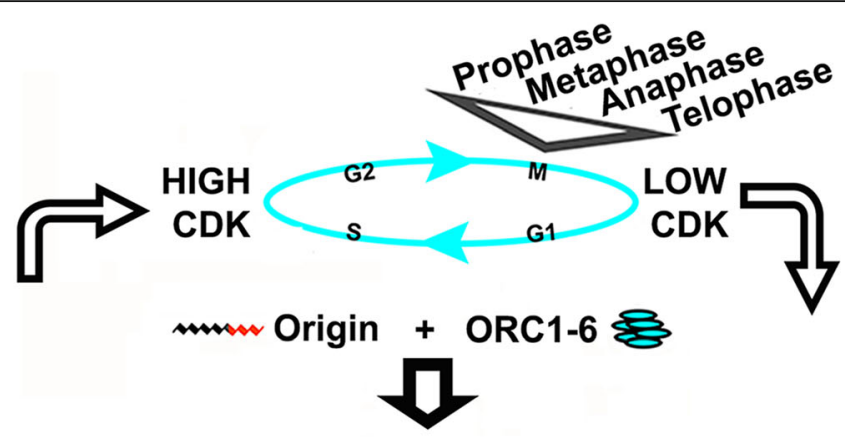

coses col1
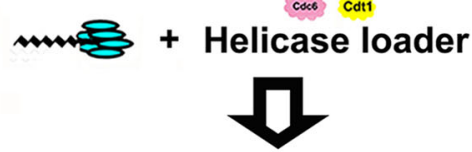

mm民3

1

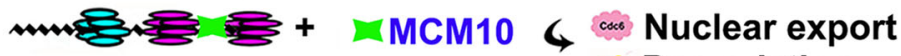

Pre-replication complex cot1 Degradation

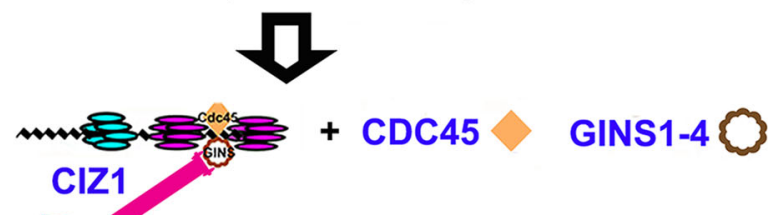

NM

Pre-initiation Complex (Pre-IC)

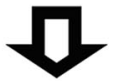

Initiation Phase Unwinding

\section{Lagging strand DNA polymerase $\delta$}

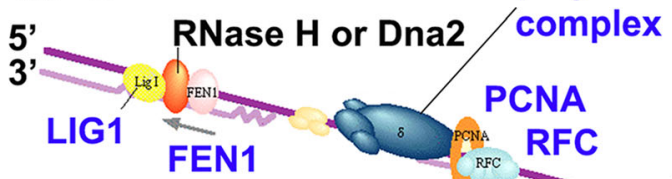

FEN1

PCNA

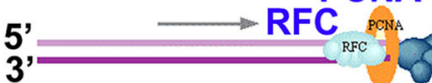

Leading strand DNA polymerase $\varepsilon$

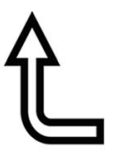
complex

DNA polymerase $\alpha$-primase complex
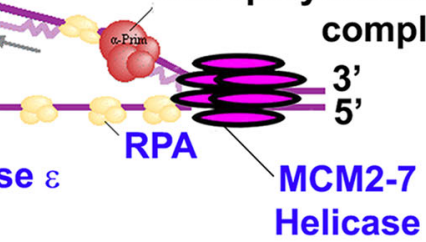

\section{Replisome}

Fig. 6 Schematic Representation Depicting Selected genes in the context of Replication. Selected genes in study (blue) [54]

for partial MMR defect in UVM. In addition to playing a role in MMR, MLH3 also has a meiotic phenotype. Evidence of MSI was observed in both tumor tissue and its normal counterpart. Mononucleotide tracks are difficult to sequence and the frequency of MSI found is implausibly high, however, some examples genuinely appear have alterations in the germline that also appear in the tumor. Interestingly, the differential expression plot across tumor types also shows CIZ1 expression is not much different between tumors and their normal 
Human DNA Damage Response

A Protein Kinase Cascade

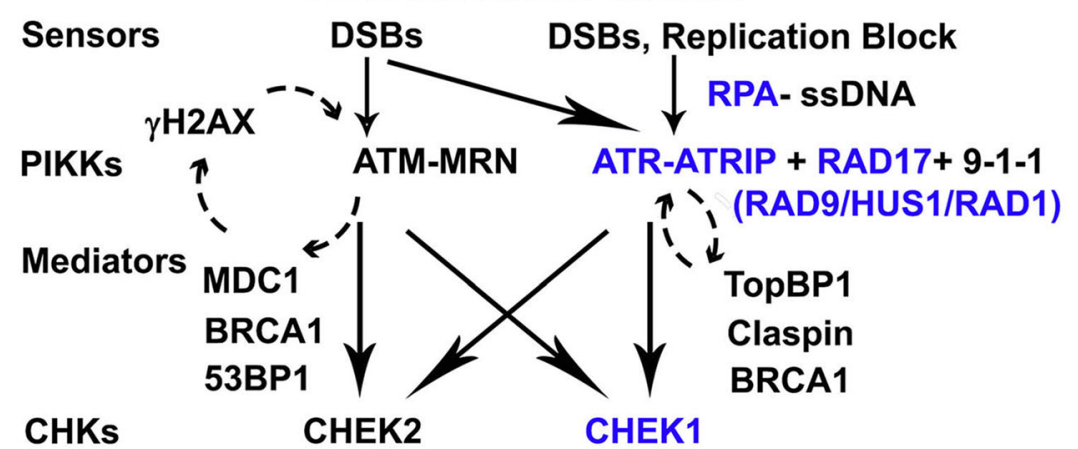

CHKs

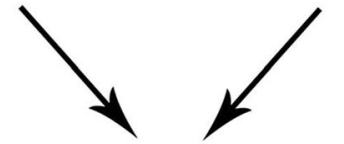

Effectors p53, BRCA1, NBS1, CDC25s, RPA, +100 s of Substrates

\section{$\downarrow$ \\ Transcription-DNA Repair-Cell Cycle Arrest-Immune Stimulation Anti-viral Functions-Metabolic Rewiring-Senescence-Apoptosis-Aging}

Fig. 7 DNA Damage Response (DDR) Pathway. Selected genes in study (b/ue) [55]

tissues quantitatively (Fig. 4), unlike MCM2 for example (Fig. 2) supporting the concept of possible predisposition.

Reviewing relative expression for PCNA (Proliferating nuclear cell antigen), FEN1 (Flap endonuclease 1), and LIG1 (Ligase 1) an increase was found that implied their involvement in overcoming RS. These components of the replisome lacked mutation and SCNA but correlated none-the less with increased expression suggesting transcriptional mechanisms were used to overcome RS and fork collapse in UVM progression. PCNA is a ring shaped homo-trimer that encircles DNA [38]. It interacts competitively with many other factors at the PIP motif $[39,40]$ and is an essential co-factor for DNA polymerases during replication. It is involved in repair processes and can also be modified post-translationally by phosphorylation, ubiquitination, SUMO proteins, ISGylation, Acetylation, and S-nitrosylation. Each modification has corresponding biological functions that include proliferation, MMR inhibition, translesion synthesis, homologous recombination, genomic stability, and apoptosis, respectively. One of its major roles is to promote tolerance to DNA damage during replication [41]. Because of its role in proliferation, PCNA is a target for cancer therapy. Several small molecules

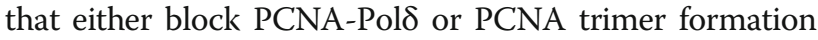

have been identified with proliferation-inhibitory effects in vitro [38, 42-44].

Two polymerases, POLD1 and POLE, important in the replication of $\mathrm{B}$ form DNA were selected for observation. The relative decrease in POLD1 expression in subtypes 3 and 4 and increase in POLE support a recently proposed model [45] in which a switch to POL $\varepsilon$ and away from POL $\delta$ occurs upon DNA damage. The behavior of POL $\alpha$ and specialized polymerases recently hypothesized to assist the replication machinery in the prevention of replication stress [4] has not yet been examined.

Replication stress activates DDR which prevents DNA damage from becoming fixed during replication and passed on in mitosis [46]. It does this in part by coordinating cell cycle control and providing a pause for repair, and in some cases by triggering apoptosis. Dysregulated DDR in a tumor cell contributes to progressive genomic instability that is cancer enabling, and can make the tumor dependent on alternative repair pathways such as base excision repair (BER) that may be targetable (e.g. Poly ADP ribose Polymerase (PARP) inhibitors). In this study we find evidence of dysregulated DDR in the more malignant subtypes. Examining individual components of DDR revealed a significant decrease in relative expression of ATRIP (ATR Interacting Protein) in clusters 3 


\section{Humans}
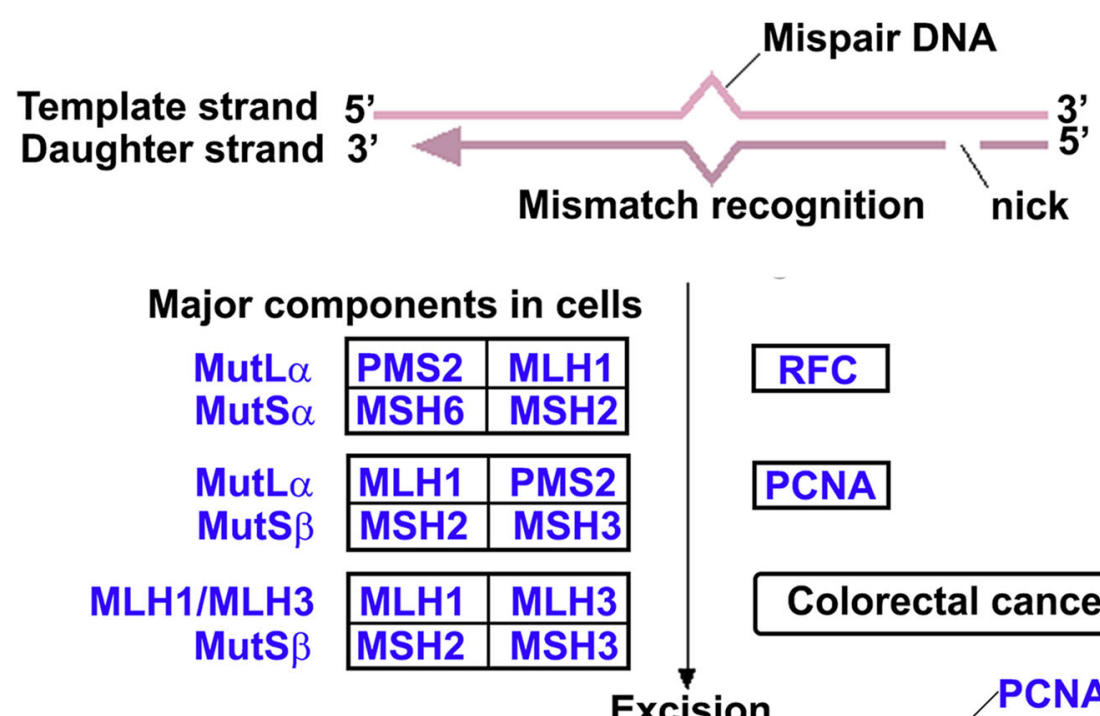

RFC

PCNA

Colorectal cancer
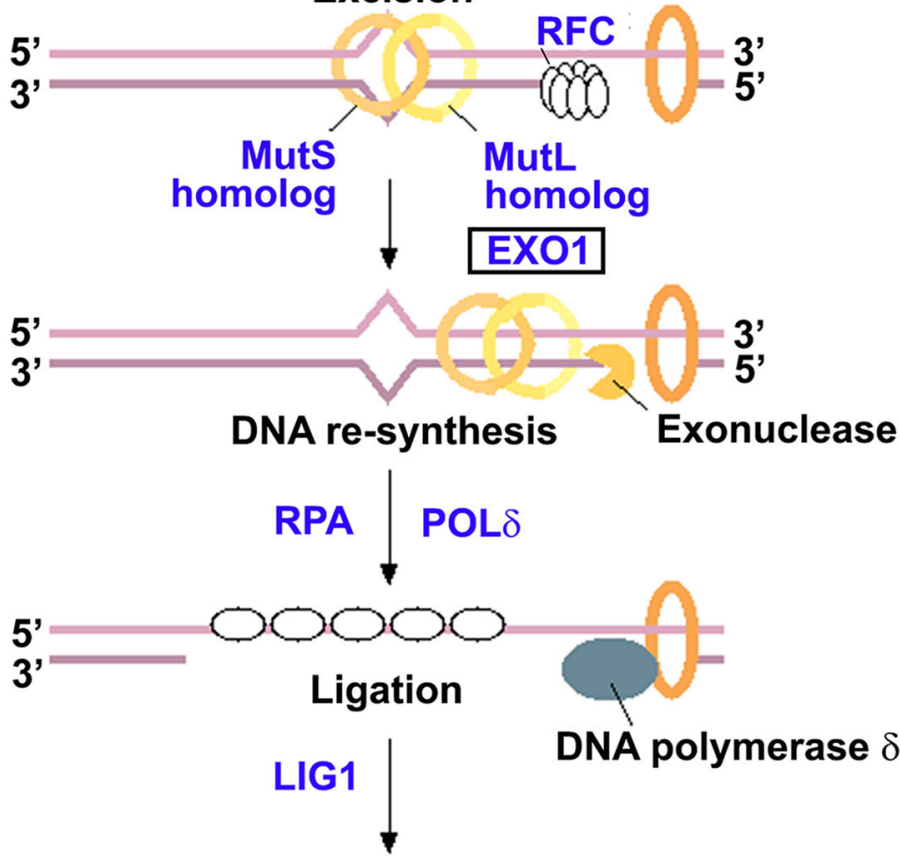

DNA polymerase $\delta$

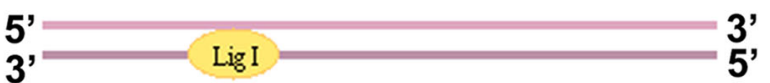

Fig. 8 Mismatch Repair (MMR) Pathway. Selected genes in study (b/ue) [54]

and 4 [47-51]. PARADIGM and MARINa algorithms previously used to examine the pathway, found protein abundance for DDR components increased suggesting DDR was active in monosomy 3/BAP1 impaired UVM [1]. ATRIP is located at 3p21.31, very close to BAP1 at $3 \mathrm{p} 21.1$. Interestingly as mentioned in the TCGA study [1], recent reports suggest that BAP1 itself may function in DDR $[52,53]$.

\section{Conclusions}

In summary, this study examines selected replication and repair factors in UVM with known biology for expression differences with and without mutation across TCGA SCNA subtypes. Differences in expression have been observed that support the concept that these genes and their products are causally involved in UVM. These data suggest further avenues 
of research for biomarker identification and therapeutic approach.

\section{Abbreviations}

BER: Base Excision Repair; DDR: DNA Damage Repair; GAF: GO Annotation File; IGV: Integrative Genomics Viewer; MCM: Mini-Chromosome Maintenance; MMR: Mismatch Repair; MSI: Microsatellite Instability; PARP: Poly ADP ribose Polymerase; RPKM: Reads per Kilobase of transcript per million mapped reads; RS: Replication Stress; RSEM: RNAseq by Expectation Maximization; SCNA: Somatic copy number alterations; TCGA: The Cancer Genome Atlas; UVM: Uveal Melanoma; WES: Whole Exome Sequencing; WGS: Whole Genome Sequencing

\section{Acknowledgements}

The author thanks Dr. Raju Kucherlapati and Dr. A. Gordon Robertson for reading the manuscript and providing comments and advice. Relative expression was determined by modifications to a method created for the analysis of structural fusions by Dr. Christopher Bristow. The work was also supported by Research Computing at Harvard Medical School, specifically Ms. Kristine Holton and Mr. Alex Truong gave very helpful consultation.

\section{Funding}

The study was supported by a grant from the National Institutes of Health to Raju Kucherlapati for the Harvard Genome Characterization Center No. 5U24CA144025

\section{Availability of data and materials}

The datasets generated and/or analyzed for the current study are available in the Genome Data Commons [9] and Broad Institute [14].

\section{Authors' contributions}

MK was solely responsible for experimental conception and design, acquisition of data, and data analysis and interpretation, manuscript drafting of important intellectual content. The author gives approval of the final version for publication, takes responsibility for the content and agrees to be accountable for accuracy and integrity.

\section{Ethics approval and consent to participate}

The project protocol for the Harvard Genome Characterization Center (HGCC) was approved by the Brigham and Women's Hospital Institutional Review Board. Access to TCGA controlled-access data was given by The Cancer Genome Atlas (TCGA) Data Access Committee. Participants agreed to participate and gave informed consent. Human Subjects Protection, Data Access Policies, and HIPAA Privacy Rule compliance were developed by the $\mathrm{NCl}$ and NHGRI to protect their privacy. This study is compliant with the TCGA "exclusivity period" for publication.

\section{Consent for publication}

Not applicable.

\section{Competing interests}

There are no competing interests financial or non-financial to declare, nor are there personal financial interests in organizations that will gain or lose by its publication.

\section{Publisher's Note}

Springer Nature remains neutral with regard to jurisdictional claims in published maps and institutional affiliations.

\section{Received: 15 November 2017 Accepted: 30 July 2018} Published online: 14 August 2018

\section{References}

1. Robertson AG, Shih J, Yau C, Gibb EA, Oba J, Mungall KL, et al. Integrative analysis identifies four molecular and clinical subsets in uveal melanoma. Cancer Cell. 2017:32(2):204-20 e15. PubMed PMID: 28810145

2. Singh AD, Turell ME, Topham AK. Uveal melanoma: trends in incidence, treatment, and survival. Ophthalmology. 2011;118(9):1881-5. PubMed PMID: 21704381
3. Krantz BA, Dave N, Komatsubara KM, Marr BP, Carvajal RD. Uveal melanoma: epidemiology, etiology, and treatment of primary disease. Clin Ophthalmol. 2017;11:279-89. PubMed PMID: 28203054. Pubmed Central PMCID: 5298817

4. Bournique E, Dall'Osto M, Hoffmann JS, Bergoglio V. Role of specialized DNA polymerases in the limitation of replicative stress and DNA damage transmission. Mutat Res. 2017: PubMed PMID: 28843435.

5. Royer-Bertrand B, Torsello M, Rimoldi D, El Zaoui I, Cisarova K, PesciniGobert R, et al. Comprehensive genetic landscape of uveal melanoma by whole-genome sequencing. Am J Hum Genet. 2016;99(5):1190-8. PubMed PMID: 27745836. Pubmed Central PMCID: 5097942

6. Gao J, Aksoy BA, Dogrusoz U, Dresdner G, Gross B, Sumer SO, et al. Integrative analysis of complex cancer genomics and clinical profiles using the cBioPortal. Sci Signal. 2013;6(269):pl1. PubMed PMID: 23550210. Pubmed Central PMCID: 4160307

7. Cerami E, Gao J, Dogrusoz U, Gross BE, Sumer SO, Aksoy BA, et al. The CBio cancer genomics portal: an open platform for exploring multidimensional cancer genomics data. Cancer Discov. 2012;2(5):401-4. PubMed PMID: 22588877. Pubmed Central PMCID: 3956037

8. cBioPortal. 2013. Available from: http://www.cbioportal.org/index.do.

9. Genome Data Commons. 2018. Available from: https://portal.gdc.cancer.gov/

10. Thorvaldsdottir $H$, Robinson JT, Mesirov JP. Integrative genomics viewer (IGV): high-performance genomics data visualization and exploration. Brief Bioinform. 2013 Mar;14(2):178-92. PubMed PMID: 22517427. Pubmed Central PMCID: 3603213

11. Robinson JT, Thorvaldsdottir H, Winckler W, Guttman M, Lander ES, Getz G, et al. Integrative genomics viewer. Nat Biotechnol. 2011;29(1):24-6. PubMed PMID: 21221095. Pubmed Central PMCID: 3346182

12. The Comprehensive R Archive network. 2018. Available from: https://cran. cnr.berkeley.edu/.

13. Liu J, Lichtenberg T, Hoadley KA, Poisson LM, Lazar AJ, Cherniack AD, Kovatich AJ, Benz CC, Levine DA, Lee AV, Omberg L, Wolf DM, Shriver CD, Thorsson V, Cancer Genome Atlas Research, Network, Hu H. An Integrated TCGA Pan-Cancer Clinical Data Resource to Drive High-Quality Survival Outcome Analytics. Cell.2018;173(2):400-16. PMCID: 6066282.

14. Broad Institute. Firehose 2016. Available from: http://gdac.broadinstitute.org/.

15. Coverley D, Marr J, Ainscough J. Ciz1 promotes mammalian DNA replication. J Cell Sci. 2005;118(Pt 1):101-12. PubMed PMID: 15585571

16. Ainscough JF, Rahman FA, Sercombe H, Sedo A, Gerlach B, Coverley D. Cterminal domains deliver the DNA replication factor Ciz1 to the nuclear matrix. J Cell Sci. 2007;120(Pt 1):115-24. PubMed PMID: 17182902

17. Copeland NA, Sercombe HE, Ainscough JF, Coverley D. Ciz1 cooperates with cyclin-A-CDK2 to activate mammalian DNA replication in vitro. J Cell Sci. 2010;123(Pt 7):1108-15. PubMed PMID: 20215406. Pubmed Central PMCID: 2844319

18. Munkley J, Copeland NA, Moignard V, Knight JR, Greaves E, Ramsbottom SA et al. Cyclin $E$ is recruited to the nuclear matrix during differentiation, but is not recruited in cancer cells. Nucleic Acids Res. 2011;39(7):2671-7. PubMed PMID: 21109536. Pubmed Central PMCID: 3074132

19. Greaves EA, Copeland NA, Coverley D, Ainscough JF. Cancer-associated variant expression and interaction of $\mathrm{ClZ1}$ with cyclin $\mathrm{A} 1$ in differentiating male germ cells. J Cell Sci. 2012;125(Pt 10):2466-77. PubMed PMID: 22366453

20. Pauzaite T, Thacker U, Tollitt J, Copeland NA. Emerging roles for Ciz1 in cell cycle regulation and as a driver of tumorigenesis. Biomol Ther. 2016;27:7(1). PubMed PMID: 28036012. Pubmed Central PMCID: 5372713

21. Rahman F, Ainscough JF, Copeland N, Coverley D. Cancer-associated missplicing of exon 4 influences the subnuclear distribution of the DNA replication factor CIZ1. Hum Mutat. 2007;28(10):993-1004. PubMed PMID: 17508423

22. Higgins G, Roper KM, Watson IJ, Blackhall FH, Rom WN, Pass HI, et al. Variant Ciz1 is a circulating biomarker for early-stage lung cancer. Proc Natl Acad Sci U S A. 2012;109(45):E3128-35. PubMed PMID: 23074256. Pubmed Central PMCID: 3494940

23. Dobbelstein $M$, Sorensen CS. Exploiting replicative stress to treat cancer. Nat Rev Drug Discov. 2015;14(6):405-23. PubMed PMID: 25953507

24. Puigvert JC, Sanjiv K, Helleday T. Targeting DNA repair, DNA metabolism and replication stress as anti-cancer strategies. FEBS J. 2016;283(2):232-45. PubMed PMID: 26507796

25. Riera A, Barbon M, Noguchi Y, Reuter LM, Schneider S, Speck C. From structure to mechanism-understanding initiation of DNA replication. Genes Dev. 2017;31(11):1073-88. PubMed PMID: 28717046 
26. Pruitt SC, Bailey KJ, Freeland A. Reduced Mcm2 expression results in severe stem/progenitor cell deficiency and cancer. Stem Cells. 2007;25(12):3121-32. PubMed PMID: 17717065

27. Shima N, Alcaraz A, Liachko I, Buske TR, Andrews CA, Munroe RJ, et al. A viable allele of Mcm4 causes chromosome instability and mammary adenocarcinomas in mice. Nat Genet. 2007:39(1):93-8. PubMed PMID: 17143284

28. Kunnev D, Rusiniak ME, Kudla A, Freeland A, Cady GK, Pruitt SC. DNA damage response and tumorigenesis in Mcm2-deficient mice. Oncogene. 2010;29(25): 3630-8. PubMed PMID: 20440269. Pubmed Central PMCID: 2892019

29. Kawabata T, Luebben SW, Yamaguchi S, Ilves I, Matise I, Buske T, et al. Stalled fork rescue via dormant replication origins in unchallenged $S$ phase promotes proper chromosome segregation and tumor suppression. Mol Cell. 2011;41(5):543-53. PubMed PMID: 21362550. Pubmed Central PMCID: 3062258

30. Rusiniak ME, Kunnev D, Freeland A, Cady GK, Pruitt SC. Mcm2 deficiency results in short deletions allowing high resolution identification of genes contributing to lymphoblastic lymphoma. Oncogene. 2012;31(36):4034-44. PubMed PMID: 22158038. Pubmed Central PMCID: 3309111

31. Kunnev D, Freeland A, Qin M, Leach RW, Wang J, Shenoy RM, et al. Effect of minichromosome maintenance protein 2 deficiency on the locations of DNA replication origins. Genome Res. 2015;25(4):558-69. PubMed PMID: 25762552. Pubmed Central PMCID: 4381527

32. Huang H, Stromme CB, Saredi G, Hodl M, Strandsby A, Gonzalez-Aguilera C, et al. A unique binding mode enables MCM2 to chaperone histones $\mathrm{H}_{3}-\mathrm{H} 4$ at replication forks. Nat Struct Mol Biol. 2015;22(8):618-26. PubMed PMID: 26167883. Pubmed Central PMCID: 4685956

33. Ishimi Y, Komamura-Kohno Y, Arai K, Masai H. Biochemical activities associated with mouse Mcm2 protein. J Biol Chem. 2001;276(46):42744-52. PubMed PMID: 11568184

34. Di Paola D, Zannis-Hadjopoulos M. Comparative analysis of pre-replication complex proteins in transformed and normal cells. J Cell Biochem. 2012; 113(4):1333-47. PubMed PMID: 22134836

35. Kikuchi J, Kinoshita I, Shimizu Y, Kikuchi E, Takeda K, Aburatani H, et al. Minichromosome maintenance (MCM) protein 4 as a marker for proliferation and its clinical and clinicopathological significance in non-small cell lung cancer. Lung Cancer. 2011;72(2):229-37. PubMed PMID: 20884074

36. Sheu YJ, Kinney JB, Lengronne A, Pasero P, Stillman B. Domain within the helicase subunit Mcm4 integrates multiple kinase signals to control DNA replication initiation and fork progression. Proc Natl Acad Sci U S A. 2014; 111(18):E1899-908. PubMed PMID: 24740181. Pubmed Central PMCID: 4020090

37. Lipkin SM, Wang $V$, Jacoby R, Banerjee-Basu S, Baxevanis AD, Lynch HT, et al. MLH3: a DNA mismatch repair gene associated with mammalian microsatellite instability. Nat Genet. 2000;24(1):27-35. PubMed PMID: 10615123

38. Choe KN, Moldovan GL. Forging ahead through darkness: PCNA, still the principal conductor at the replication fork. Mol Cell. 2017;65(3):380-92. PubMed PMID: 28157503. Pubmed Central PMCID: 5302417

39. De Biasio A, Blanco FJ. Proliferating cell nuclear antigen structure and interactions: too many partners for one dancer? Adv Protein Chem Struct Biol. 2013;91:1-36. PubMed PMID: 23790209

40. Boehm EM, Washington MT. R.I.P. to the PIP: PCNA-binding motif no longer considered specific: PIP motifs and other related sequences are not distinct entities and can bind multiple proteins involved in genome maintenance. BioEssays. 2016;38(11):1117-22. PubMed PMID: 27539869. Pubmed Central PMCID: 5341575

41. Stoimenov I, Helleday T. PCNA on the crossroad of cancer. Biochem Soc Trans. 2009:37(Pt 3):605-13. PubMed PMID: 19442257

42. Wang SC. PCNA: a silent housekeeper or a potential therapeutic target? Trends Pharmacol Sci. 2014;35(4):178-86. PubMed PMID: 24655521

43. Smith SJ, Gu L, Phipps EA, Dobrolecki LE, Mabrey KS, Gulley P, et al. A peptide mimicking a region in proliferating cell nuclear antigen specific to key protein interactions is cytotoxic to breast cancer. Mol Pharmacol. 2015; 87(2):263-76. PubMed PMID: 25480843. Pubmed Central PMCID: 4293449

44. Gu L, Smith S, Li C, Hickey RJ, Stark JM, Fields GB, et al. A PCNA-derived cell permeable peptide selectively inhibits neuroblastoma cell growth. PLoS One. 2014;9(4):e94773. PubMed PMID: 24728180. Pubmed Central PMCID: 3984256

45. Stillman B, Reconsidering DNA. Polymerases at the replication fork in eukaryotes. Mol Cell. 2015;59(2):139-41. PubMed PMID: 26186286. Pubmed Central PMCID: 4636199
46. Rundle S, Bradbury A, Drew Y, Curtin NJ. Targeting the ATR-CHK1 Axis in Cancer Therapy. Cancers (Basel). 2017:9(5):41. PubMed PMID: 2844862 Pubmed Central PMCID: 5447951.

47. Zou L, Elledge SJ. Sensing DNA damage through ATRIP recognition of RPAssDNA complexes. Science. 2003;300(5625):1542-8. PubMed PMID: 12791985

48. O'Connell BC, Adamson B, Lydeard JR, Sowa ME, Ciccia A, Bredemeyer AL, et al. A genome-wide camptothecin sensitivity screen identifies a mammalian MMS22L-NFKBIL2 complex required for genomic stability. Mol Cell. 2010;40(4):645-57. PubMed PMID: 21055985. Pubmed Central PMCID: 3006237

49. Cortez D, Guntuku S, Qin J, Elledge SJ. ATR and ATRIP: partners in checkpoint signaling. Science. 2001;294(5547):1713-6. PubMed PMID: 11721054

50. Cortez D, Glick G, Elledge SJ. Minichromosome maintenance proteins are direct targets of the ATM and ATR checkpoint kinases. Proc Natl Acad Sci U S A. 2004;101(27):10078-83. PubMed PMID: 15210935. Pubmed Central PMCID: 454167

51. Burrows AE, Elledge SJ. How ATR turns on: TopBP1 goes on ATRIP with ATR. Genes Dev. 2008;22(11):1416-21. PubMed PMID: 18519633. Pubmed Central PMCID: 2732414

52. Ismail IH, Davidson R, Gagne JP, Xu ZZ, Poirier GG, Hendzel MJ. Germline mutations in BAP1 impair its function in DNA double-strand break repair. Cancer Res. 2014;74(16):4282-94. PubMed PMID: 24894717

53. Yu H, Pak H, Hammond-Martel I, Ghram M, Rodrigue A, Daou S, et al. Tumo suppressor and deubiquitinase BAP1 promotes DNA double-strand break repair. Proc Natl Acad Sci U S A. 2014;111(1):285-90. PubMed PMID: 24347639. Pubmed Central PMCID: 3890818

54. KEGG Pathway Database. 2018. Available from: https://www.genome.jp/kegg/ pathway.html.

55. Elledge S. 2018. Available from: http://elledgelab.med.harvard.edu/?page_id=264).
Ready to submit your research? Choose BMC and benefit from:

- fast, convenient online submission

- thorough peer review by experienced researchers in your field

- rapid publication on acceptance

- support for research data, including large and complex data types

- gold Open Access which fosters wider collaboration and increased citations

- maximum visibility for your research: over 100M website views per year

At $\mathrm{BMC}$, research is always in progress.

Learn more biomedcentral.com/submissions 